\title{
CONSPIRACY OF FUN: BREAKING DRAMATIC ILLUSION IN ROMAN COMEDY* $^{*}$
}

\author{
Louise Cilliers (University of the Free State)
}

\section{The remarkable phenomenon of dramatic illusion}

One of the most remarkable phenomena in dramatic performances is the way in which adults get involved in the events on the stage, to the extent of going through agonies of suspense, fear and pity while knowing full well that these events are pure make-believe. ${ }^{1}$ It is even more remarkable that this capacity for living in two worlds simultaneously-one real, one imaginary-was accepted as a commonplace for so many centuries. Only recently did drama theorists and psychologists start doing research on the complex problem of spectators'/viewers' emotional reaction to art and literature, ${ }^{2}$ thereby casting some light on the intricate question of the extent to which spectators/viewers become immersed in the illusionary world of the stage/screen and identify with the characters.

\section{Theatre of illusion vs. theatre of convention}

The effect aimed at in the presentation of most modern dramas and TV and cinema films is to reach as close an approximation to reality as possible. This differs from the presentation of ancient Greek and Roman dramas, where the dramatic situations did not necessarily truthfully imitate situations of everyday life, and the characters were usually not, from a psychological point of view, true to life.

These two divergent kinds of presentation make different demands on the audience. P. D. Anott (1961:6) explains it by the image of a child who is dressed in a detailed copy of a cowboy outfit and acts like a cowboy-an attempt to create the illusion of reality, which may be compared to the dramas of, for instance, Ibsen and Chekhov and which Arnott calls "the theatre of illusion". In this kind of

\footnotetext{
In his introduction to Pirandello's Six Characters in Search of an Author, Lionel Trilling wrote: "The word 'illusion' comes from the Latin word meaning 'to mock' (illudere), which in turn comes from the meaning 'to play' (ludere), and a favourite activity of the theatre is to play with the idea of illusion itself, to mock the very thing it tries to create-and the audience that accepts it" (quoted by Styan 1975:180). Hence the title of this article: Conspiracy of Fun ...
}

1 Cf. Cicero's reference in his De Amicitia 7.24 to an incident which reportedly happened in the early 2nd century B.C.: "What shouts recently ran through the entire theatre during the performance of the new play ... at a scene where (the king being ignorant which of the two was Orestes) Pylades-who wished to be put to death instead of his friend-declared, 'I am Orestes', while Orestes continued steadfastly to assert as was the fact, 'I am Orestes'. The people in the audience rose to their feet and cheered this incident in fiction ..."

2 Cf. Poetics 23 (1995) which is as a whole devoted to "Emotions and Cultural Products". 
presentation the spectators are enticed to become so thoroughly engrossed in the illusion of reality created by the characters that they become oblivious of the fact that they are watching a play. Greek and Roman dramas on the other hand belong in a category which Arnott designates "the theatre of convention", illustrated by the image of a child who puts a ring of paper on his head, stands on a chair and says: "I'm king of the castle". In this non-illusory kind of theatre the spectators have to co-operate and participate by accepting, understanding and interpreting certain standard practices. The basic difference between the two kinds of theatre is thus the degree of illusion entered into by the audience: in the theatre of convention the spectator will have a greater awareness of the fact of performance than in the illusionistic theatre. ${ }^{3}$

\section{Balance between illusion and awareness of the play-element}

Even though spectators watching illusionistic theatre can become completely absorbed in the events on the stage and forget that they are in a theatre, some awareness of the play-element is necessary in order to make it an aesthetic experience. Children and naive audiences can become so involved that they completely forget their surroundings and believe the events on the stage to be real; this, however, according to Calderwood and Toliver, is not an aesthetic experience, but a kind of hypnotic trance: "The aesthetic experience depends on the delicate balance arising from the presence of both matrices (i.e. the real and the imaginary) on the mind ..." (1968:242).

The audience should thus constantly be aware that the actors represent, that is pretend to be, ${ }^{4}$ the characters of the play. In this regard E. Burns distinguishes between two levels in the relationship between actor and spectator: "On one level actors and spectators see each other for what they are, disguised or undisguised, related to each other according to the demands of the occasion. On another level the spectators see the characters in the play while the actors 'in character' behave as if the spectators were invisible" (1972:31). There is, as R. C. Beacham remarks, "no question of suspension of disbelief; the spectators and performers are simultaneously inside and outside the world of the play" (1991:35)..$^{5}$

3 This distinction between the two kinds of theatre resembles to some extent that of Bertold Brecht who differentiates between the "merry-go-round" type of theatre in which the spectators are like children who "travel along" and get totally involved, and the "planetarium" type in which the spectators are like adults who critically view the events from afar (1963-1965:65-69). Brecht's epic theatre obviously belonged to the latter category; however, he never referred to ancient comedy.

4 D. Bain (1977:6) prefers to use the word 'pretense' instead of 'illusion', because according to him the term 'dramatic illusion' implies that the audience is in some way deceived by what goes on on the stage, and confuses play-acting and reality. Bain's argument is that "actors pretend to be the people they play and the audience accepts that pretense".

Cf. too Bain (1977:6) who believes that it is perfectly possible for the audience of an 'illusionist' play to be at the same time emotionally involved in the action and in possession of its critical faculties. 
The same balance between regard for the play-element and immersion in the events on the stage has to be considered in the theatre of convention. Here, on the other hand, the problem may be that the element of illusion is not sufficiently in evidence. ${ }^{6}$ There are in fact scholars who believe that the psychological phenomenon of illusion was totally alien to Greek and Roman plays. ${ }^{7}$ This view is to some extent understandable, since a depiction of reality was hardly possible in these outdoors, daylight performances with (in Greek comedies) a chorus stationed between the actors and the audience right through the play, and with the actors wearing masks, costumes and speaking in verse rhythm. However, every play presupposes a degree of dramatic illusion, ${ }^{8}$ although there is a distinct difference between the theatre of illusion and the theatre of convention in this regard. In the former the actor tries his best to persuade himself and the audience that he is person A or B (and he often succeeds), whereas non-illusory theatre presupposes "a kind of implicit agreement on the rules of the performance (established by long tradition) between the actors and the audience" (Sifakis 1971:10), a conspiracy, as it were, in accordance with which the audience consents to accept the claim of the actor to be person A or B, and to believe that the fictional world on the stage is what it is supposed to be. Keir Elam describes this theatrical agreement or contract as "the product of a set of transactional conventions governing the participants' expectations and their understanding of the kinds of reality involved in the performance” (1980:88). ${ }^{9}$

\section{Effects of the disruption of the dramatic illusion}

Before considering the question of what the effect of the violation of such a theatrical agreement would be, i.e. what the effect of the disruption of the dramatic illusion would be, it should be pointed out that though from a modern point of view one may be tempted to view the theatre of illusion as the norm, 10 it is in fact only

6 In fact, the concept of 'dramatic illusion' does not occur in ancient literary theory, although the phenomenon was obviously known and employed. The Greek word apate which literally means 'deceit' as used by Gorgias with regard to tragedy is the nearest in meaning (cf. the brief discussion in Görler 1973:42 n.50). The clearest example of dramatic illusion in antiquity was given by Horace $E p$. 2.1.210-213:

Ille per extentum funem mihi posse videtur

ire, poeta meum qui pectus inaniter angit, inritat, mulcet, falsis terroribus implet

ut magus, et modo me Thebis, modo ponit Athenis.

7 Cf. G. M. Sifakis (1971:7) who believes that "the use of the term (sc. illusion) with reference to Greek drama is an anachronism".

8 Cf. Brecht's criticism of the tendency, or primeval instinct, of audiences "... sich in Illusion $2 u$ werfen" (1963-1965:3.156).

9 Cf. too W. Passow (1981:83) who describes the relation between actor and andience as a "contrat theatral" according to which the spectators accept that the events in a theatre are pure make-believe. Cf. J. L. Styan (1975:218) who speaks of "the persistent expectation of realism ..." 
one of the options of dramatic communication. ${ }^{11}$ Greek Old Comedy with Aristophanes as its main exponent ranged between illusionary and non-illusory theatre; Greek New Comedy opted for illusion, trying to maintain a surface realism; Plautus in turn reacted against this illusionism and more often than not poked fun at it, whereas Terence was closer to Menander with his realistic presentation.

In the light of the foregoing, Slater comes to the conclusion that "to speak of illusion-breaking in these circumstances, then, is somewhat misleading" (1985:148). Such a view would be apposite in the case of a drama in which the theatrical frame is discredited so often and the transition from audience address to action is so swift that "the spectators cannot establish a clear formula for assessing the actor and his role" (Grube 1986:18). This is obviously not the case in Terence's comedies, nor would such a description fit Plautus' plays. Though interspersed with numerous non-illusory devices, even the latter remain basically illusionary-sufficiently so to allow a theatrical contract between actor and audience to be entered into.

It stands to reason, however, that such a theatrical contract will be affected in some way by the use of non-illusory devices. A violation of the illusion will obviously also cause an interruption in the line of action and the building up of suspense, a situation which would normally be considered undesirable. But why is it then that the plays of Plautus, which abound in the breaking of the illusion, were so popular in antiquity?

In order to answer this question, it is necessary to take a closer look at the effect of the various non-illusory devices which were used in Roman comedy. The most frequently occurring devices are the monologue, the aside, eavesdropping, role-playing and the play-within-the-play. ${ }^{12}$ In this article, attention will be paid only to manifest cases of the disruptions of the illusion such as occur in direct audience addresses, for instance, in the prologue, epilogue, and in the course of the action as will be indicated. 13

\subsection{In the prologue}

The most obvious kind of direct audience address is found in places which are, strictly speaking, outside the dramatic action, namely the prologue and the epilogue. Since the plays which have prologues mostly start with a direct audience address, one can hardly call it a disruption of the illusion; however, attention will be paid to this phase since the commencement of a play offers insight into the way in which a

11 Cf. Slater 1985:10: "Illusion is not the aim of all theatre" and "... realism is merely another convention."

12 These devices are discussed by Slater $(1985: 12,147-167)$. Cf. too in this regard Bain 1977:154-184.

13 Although there may be some overlapping with the aside, this device is not treated in the following discussion, since an aside may either be an audience address or merely a thought expressed aloud, which is not such an obvious disruption of the illusion. In order to establish the effect of such disruptions as clearly as possible, only the most obvious cases are discussed here. 
dramatist handles the transition from the real world to the world of the play, i.e. from reality to illusion. It is furthermore interesting to see what the effect is of the different approaches of Plautus and Terence.

In the prologue, the Roman playwright had the unenviable task of quietening down a large, unruly crowd, of obtaining their attention and goodwill, and of creating the right kind of atmosphere for the play. Plautus seems to have succeeded very well here: in most of his plays which have a prologue the audience is given time to settle down while the speaker-with many jokes and wisecracks in betweenwelcomes the spectators, gives the necessary background information and requests the audience's attention. There are, however, also plays where the action starts immediately (e.g. the Cist., Curc., Epid., Ps., Most., Stich. and Pers.) and others with a delayed prologue (e.g. the Mil. 79ff.)-in these cases the spectators are plunged into the illusion at the start and their attention is gripped immediately, but broken of course when the delayed prologue is recited.

Terence on the other hand is not much concerned about the spectators ${ }^{14}$-his plays start with a serious prologue resembling an author's preface, in which he argues with the critics and defends his craft, the speaker of the prologue acting as his mouthpiece. There is very little illusion in such a set speech, apart from the fact that it is delivered by an actor addressing an audience from the stage.

The end of the prologue brings us to another transition, this time to the play proper. Although there is in the prologue already the aforesaid (limited) degree of illusion, it differs from that in the play itself-in the prologue the actor in his address to the audience appears as an actor, not as a character in the play.

The transition from the prologue to the illusionary world of the play is also handled differently by Plautus and Terence. In the plays of Plautus which have a prologue, one sometimes finds an explicit warning of the coming transition, 15 a waming which is obviously intended to be humorous, consisting as it does of a blunt reference to the theatrical transaction and to the fictional status of the play to come. ${ }^{16}$ This approach normally occurs when the actor delivering the prologue is unidentified and not (or rather not yet) a character in the play. On other occasions, usually when the prologue speaker is a character in the play, we are led directly from the outline of the plot into the play. ${ }^{17}$ Once again one finds that Plautus takes

14 In fact, Terence's attitude to his audience is full of contempt, as is clear from his reference to the populus stupidus in Hec. 4. However, Slater (1985:6) refers to recent research which showed that Roman audiences were far from ignorant of the nature and devices of the theatre.

15 Cf. Poen. 126: ibo, alius nunc fieri volo; Men. $71 \mathrm{ff}$. : haec urbs Epidamnus est, dum haec agitur fabula, / quando alia agetur, aliud fiet oppidum; Truc. 10ff.; Capt. 54ff.

16 Slater (1985:151) is correct in saying that this kind of prologue which emphasizes the theatricality of the play by making explicit the transition from one mode of perception to another, draws the audience "not into illusion but into participation in the creation and functioning of the play".

17 Cf. Merc.; Amph.; Aul.and Rud. (though in the latter two plays the speaker of the prologue does not take part in the play but directs the course of the action). 
his audience into consideration: he takes pains to bring about a smooth transition by merging reality into illusion, or at any rate preparing the audience for it.

In Terence's prologues the spectator is plunged into a literary controversy which usually ends abruptly with a request for a fair hearing. This literary approach hardly puts one in a receptive mood and provides no preparation for the transition to the world of the play. It must be borne in mind that the theatrical contract depends on the "self-conscious willingness" (Beacham 1991:90) of the audience to be deluded. Plautus' plays, in which the appropriate atmosphere is created from the start, require much less of an effort to make the transition into the play-world. This approach would undoubtedly have contributed to a greater enjoyment of his plays by the audience.

\subsection{In the epilogue}

The other very obvious violation of the dramatic illusion is in the epilogue. There is no difference between Plautus' and Terence's approach here. The transition from the play world to reality is abrupt-but, then, the play is over and the spectators must return to the real world. Since there was no curtain to indicate the end of the play, one of the actors usually turned to the audience and asked for applause. ${ }^{18}$ Sometimes the epilogue contained a brief exposition of what happens to the characters once the play is over (e.g. Cas. 1012-1018 and Cist. 782-784) or a plea for a culprit (e.g. Asin. 942-927 and Bacch. 1207-1211), or a mock invitation, not to a feast, but to the next day's performance (e.g. Ps. 1330-1335)-a clear illustration of the conspiracy of fun!

\subsection{In the course of the play}

Apart from these conspicuous ruptures of the dramatic illusion in the prologue and the epilogue, there are many occasions in the course of the play where the audience is addressed directly by one of the characters-especially in Plautus' comedies. One finds, for instance, requests to the audience not to divulge important information, 19 requests for help ${ }^{20}$ and entreaties in which the audience is asked to substitute for a character who is in a fix (e.g. Cas. 948-949 and Most. 354-361). In all these

18 Cf., i.a., Plautus Most. 1181: Spectatores, fabula haec est acta, vos plausum date; Men. 1163; Merc. 1025-1026; Terence Phorm. 1055: Vos valete et plaudite.

19 Cf. Men. 879-881 where Menaechmus II, pretending to be mad, asks the audience not to tell the old man which way he went (vosque omnis quaeso, si senex revenerit, I ne me indicetis qua platea hinc aufugerim); also Mil. 862 where the drunken Lucrio tries to escape punishment by running away, and asks the audience not to tell his master about his carousing (ne dixeritis, obsecro, huic, vostram fidem).

20 Cf. Men. 999-1000, where Menaechmus I's father-in-law orders the slaves to take Menaechmus II to the doctor, thinking he is mad, and Menaechmus II requests the audience's help (...perii, opsecro vestram fidem / Epidamnienses, subvenite, cives ...); and Cist. 678-681, where the slave woman asks the audience's help in her search for the casket. 
instances the spectators will, because of knowledge imparted to them which the other characters do not share, be drawn into the action and become allies, as it were, in the fight against a common enemy. Though the action is temporarily interrupted by these remarks, the suspense is heightened.

The illusion is furthermore often ruptured by humorous remarks ${ }^{21}$-it is, after all, a comedy full of fun, and the audience is never allowed to forget that the performance is nothing but a game.

Then there are comments on or explanations of events taking place on stage, 22 or in the case of a course of events which may be confusing, a clue of what is to be expected. ${ }^{23}$ In these cases too more knowledge automatically leads to greater involvement of the spectator/reader.

Finally, a frequently recurring form of audience address is the reference to stage properties, ${ }^{24}$ to other plays ${ }^{25}$ or actors ${ }^{26}$ or to the audience itself. 27 Here the spectator is drawn in behind the scenes-he is given the opportunity of viewing the functioning of the play from the actors' point of view, and is made actively conscious of the theatrical experience. This involvement of the audience would have added to their enjoyment of the play, and since, as the examples show, it was mainly Plautus who indulged in this approach, it would have contributed to his popularity.

21 Cf. Curc. 462-484 where the actors' property manager gives the audience information on how to while away the time until Curculio reappears; Bacch. 1072-1074 where the servus callidus, Chrysalus, explains why he does not get more credit for the excellent trick he played on the senex, cf. too Most. 280-281; Mil. 1131; and Stich. 446-448.

22 Cf. Cas. 683-685 where the audience is informed about a trick that is being played on one of the characters on stage, and Cas. 879-890 where Olympio tells the audience about the disgrace he has suffered; Stich. 673-682 where the maid Stephanium explains to the audience why she appears from one house though she lives in another; Truc. 484-492 where Stratophanes explains his own behaviour; Mil. 200-218 where Periplectomenus remarks on Palaestrio's poses as the latter is devising a plan of action; Ps. 562-514 where Pseudolus promises the audience that he will do what he has promised to do.

23 Cf. Amph. 463-497, 861-881 and 984-1008 where the audience is informed about what is to happen, since the characters Jupiter and Mercury, acting as Amphitryon and Sosia, may cause confusion.

24 Cf. Curc. 464 where the manager of the company of actors remarks that the costumes which have been hired out will almost certainly be gone for good; Poen. 597-599 where the counsellor tells the audience that what they see is not real money, but stage money.

25 Cf. Ps. 237 and 1239-1241 where Simo refers to other comedies where things happen in a different way.

26 Cf. Bacch. 214-215 where there is a reference to the play Epidicus which Chrysalus likes to see but not when Pellio plays in it.

27 Cf. Ps. 720-721 where the remark is made that the play is being acted for the benefit of the spectators; Poen. 920-921 where Milphio tells the audience that he will give the information to his master since the audience has heard it already; Poen. 1224 where Agorastocles says the audience is anxious to hear the information. 


\subsection{Disruptions of illusion merely extension of the theatrical frame}

These audience addresses and also those discussed earlier thus have the effect of getting the reader (and probably much more so the spectator) involved not only in the course of the action, but also, as it were, in the making of the play. In a casual, informal way the audience is drawn into the dramatic action and becomes part of the play.

The disruption of the dramatic illusion is thus not experienced negatively; although the action is temporarily interrupted, the illusion is re-established when the action is resumed. One could say that the disruption merely implies an extension of the frame of the fictional world: a new situation is created. In his discussion of the conventions of the theatrical frame, Keir Elam (1980:90) refers to premeditated disruptions of the dramatic illusion as "metadramatic and metatheatrical functions", since they bring attention to bear on the theatrical and dramatic realities in the play, ${ }^{28}$ on the fictional status of the characters, and on the theatrical transaction or contract itself.

\section{Conclusion}

A few observations can be made on the ground of the foregoing investigation. First, it is clear that the breaking of the illusion as handled by Plautus and Terence does not have a disturbing effect on the course of the action. The reason is that the illusion is never completely broken; when a character addresses the audience and the action on the stage is exposed as fictitious, the 'reality' of another fiction is asserted. The character steps out of the 'collective illusion' of the play and creates a 'subplay' in which he is the only actor. We are merely transposed from one level of illusion to another. This view is confirmed by Mouton in her discussion of Chris Fourie's drama, Ek, Anna van Wyk (1989:84), in which the illusion is repeatedly disrupted when the actress steps out of her role, but re-established when the drama resumes its fictional mode. Even during the disruption the fictional mode or illusion is maintained since the actress still plays a role, namely that of an actress.

A second reason why the breaking of the illusion is not as disturbing as one would expect, is that, though the line of action may be interrupted, the line of suspense is not broken, but merely temporarily suspended while the spectator is, as it were, drawn into the events and becomes an accomplice in the intrigues on the stage. This has a direct influence on the building up of suspense in that the audience will feel more anxious about dangers threatening the characters.

Because of his more realistic presentation, one finds fewer breaks in the dramatic illusion in Terence's plays. Plautus on the other hand delighted in breaking

28 Cf. in this regard Abel 1963:40-113, Styan 1975:180-241, and in particular Slater 1985. The latter discusses some of Plautus' plays from the perspective of theatrically self-conscious theatre, for instance, of the awareness of the play as a play. 
the illusion. Whereas his predecessor Menander and others after him sought to imitate life as realistically as possible, Plautus had fun with the very idea of imitation and emphasized the theatricality of his plays. This provided an added source of humour, and is yet another reason for his greater popularity amongst contemporaries.

\section{BIBLIOGRAPHY}

Abel, L 1963. Metatheatre: A New View of Dramatic Form. New York: Hill \& Wang.

Amott, P D 1961. An Introduction to the Greek Theatre. London: Macmillan \& Co. Bain, D 1977. Actors and Audience: A Study of Asides and Related Conventions in Greek Drama. Oxford: Oxford University Press.

Beacham, R C 1991. The Roman Theatre and Its Audience. London: Routledge. Brecht, B 1963-1965. Schriften zum Theater. Frankfurt am Mainz: Suhrkamp.

Burns, E 1972. Theatricality: A Study of Convention in the Theatre and Social Life. London: Harper \& Row.

Calderwood, J L \& Toliver, H E 1968. Perspectives on Drama. Oxford: Oxford University Press.

Elam, K 1980. The Semiotics of Theatre and Drama. London and New York: Methuen.

Görler, W 1973. Über die Illusion in der antiken Komödie. Antike und Abendland 18, 41-57.

Grube, W E 1986. Comic Theatres: Studies in Performance and Audience Response. Athens and London: University of Georgia Press.

Mouton, M 1989. Dramateorie vandag: Die bydrae van die drama- en teatersemiotiek. Potchefstroom: PU vir CHO, Sentrale Publikasies.

Passow, W 1981. The Analysis of Theatrical Performance. Poetics Today 2.3, 7093.

Sifakis, G M 1971. Parabasis and Animal Choruses: A Contribution to the History of Attic Comedy. London: Athlone Press.

Styan, J L 1975. Drama, Stage and Audience. Cambridge: Cambridge University Press.

Slater, N 1985. Plautus in Performance: The Theatre of the Mind. Princeton: Princeton University Press. 